\title{
一講義および解說一
}

\section{熔接構造物の放射線檢查 $(1)$}

石井勇 五 郎*

\section{はしがき}

$\mathrm{X}$ 線， $\gamma$ 線の透視抽よび透過検查によって金属内部を間 接に透視できるようになった結果，鋳造技術または熔接技 術が非常な進歩をもたらしたととは周知の事実である。し かし放射線による検査の適用範囲は未だ数多くの開拓され る余地を残している. 放射検查は他の滲透検査や電磁検查 または超音波検査に比し欠陹の検出像に最も直観性があり しかも検出精度が大きいために広く利用されている，熔接 部の検査は被検物の厚さからいって放射線検査に最も適し て㧍り，現在は放射線検査の伴なわない熔接施行は皆無に 近い．以下に放射線検査の全貌を述べ今後の発展の予想， 熔接の欠陌像むよび強度との関係について述へてみよう.

\section{1 放射線の性犋}

X線とは人工的に高速の電子を物質にあてた際その衝突 した所から発生する電磁波であり， $\gamma$ 線とは放射性物質か ら発生するX線と同じすので習慣に従って区別しているに 過ぎなく本質的に同じものである.

$\mathrm{X}$ 線は線スペクトルからなる特性 X 線と連続スヘクトル からなる連続または白色X線からなる、しかし軽金属や薄 物の検查以外飞は特性 X線は関係が浅い，特性 X線は電子

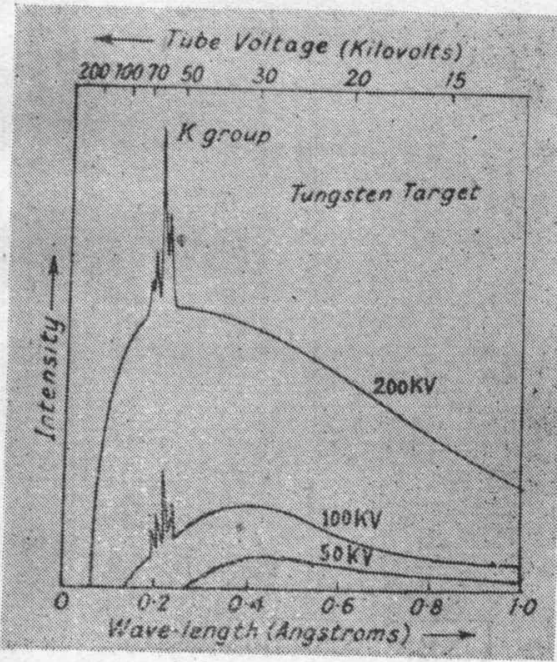

Fig. 1 Composition of X-ray bcam の衝突する 物質の元素 飞特有なも のであるが 白色 X線は 元素江無関 係に電子を 加速する電 压よって 波長分布が 決る.その 発生 $\mathrm{X}$ 線の 全エネルギ 一は電流飞 比例し, 電

* 運輸技術研究所
大体比例する. しかし物質を透過するX線は波長の長い方 が多く吸収されるため，電圧が低いほど，透過物の厚さが 大きいほどエネルギーの減少する割合が多くなり，結局物 質を透過してフィルムの感光にあずかるX線のエネルギー には自乗法則が成立しなくなり，電圧の数乗自至十数乗に 比例するようになる.すなわちこれは発生する $\mathrm{X}$ 線の最短 波長は電子の加速電圧によって決り，電圧が高ければ高い ほど最短波長が短くなり,エネルギーの最大も Fig. 11)の ごとく短波長の方に移るからである. その最短波長は $e$ の 電価を有する電子が $V$ ポルトで加速されたとき $e V$ の ホルギーを得るが（1電子ボルトは $1.59 \times 10^{-12} \mathrm{erg}$ ) その 全エホルギーが X線のエネルギーに変換したとすればその 光子のエネルギー $h \boldsymbol{\nu}$ と等しくなるため ( $h$ は Planck の 常数 $6.55 \times 10^{-12} \mathrm{erg} \mathrm{sec}, \nu$ は振動数で波長 $\lambda$ を $\AA$ で表 わせば $\nu=c \lambda, c$ は $\left.3 \times 10^{10} \mathrm{~cm} / \mathrm{sec}\right) V$ を $\mathrm{kV}$ で表わせば

$$
\lambda=\frac{h c}{e V}=\frac{12.35}{V} \AA
$$

となる. しかし電子の有するエホルギーは非常に僅か ( 1 〜 $2 \%$ 以下) しかX線のエホルギーに変換しない Fig. 1 からあ知られるごとく高電圧になれば变換率は大となる。 $\gamma$ 線は放射性元素が崩壊， $\beta$ 崩壊または中性括よび $K$ 電 子捕獲等の核反応によって生成した原子核が一般にエネル ギーの高い励起状態にあり, これが $\gamma$ 線を出して安定した 原子核になる際 $10 \mathrm{KeV} \sim 6 \mathrm{MeV}$ の範囲の線スペクトルと して発生して来る. しかし透過検査に使用し得る $\gamma$ 線源は 一般はX 線に比し全エネルギーは小さい，すなわち単位時 間に発生するエネルギーを大にするには崩壊原子数を多く しなければならず,それには量を多くするか, 半減期の短 いものを択へばよいがいずれも透過検查に対して焦点が大 きくなるか，使用期限が短縮するなどの不便がおこるため である.

$\mathrm{X}$ 線， $\gamma$ 線が物質に大射した場合，その物質と作用し Fig. 2 に示すような各種のX線または電子を放出する. し かし検査に最も必要なのは透過して来る一次 X 線 (transnitted primary X-ray) であり，その他は吸収された一次

1) Ulreyの曲線とMember of the I.R.G. of Inst. Phys ; Handbook of Industrial Radiogrophy 1949 から転 載. 


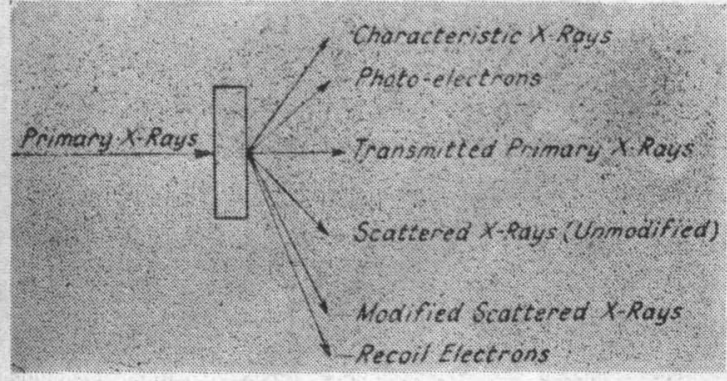

Fig. 2

X線のエネルギーが変換したあのであり，透過検査に対し ては像を不鮮明にする有害なるのである.

透過検查に和いてX線， $\gamma$ 線を利用するのは吸収が厚さ によって変るので欠陌が存在すればそれだけ吸收が少なく 透過 X線の量に変化を生し，この変化がフィルムまたは螢 光板に欠宿の像として現われるのである. 従ってX線、 $\gamma$ 線の吸収を述べる必要がある。

一般に同一厚さの同一物質でX線が吸収される割合はX 線， $\gamma$ 線の波長が短いほど吸収され難く，物質が異なると きは物体を構成する元素の原子番号の大きいほど吸収され やすい，しかしX線が投射される物質が発生する特性 X線 の波長より短い所飞吸収率が急に大きくなる所が存在す る. これをその物質の吸収端と呼び物質に固有なものであ る. しかし透過検査では多くは特性線より短い波長を用い るのであまり問題はない，吸収によってX線， $\gamma$ 線の減衰 する様式の主なあのは次のようなあのが挙げられる.

i) 光電効果 (Photo electric effect)

光子が消滅して原子核に近い電子が高速で飛出す現象で 放射線のエネルギーが低いほど，または原子番号 Zの大き い元素ほど顕著であり，その起る確率は近似的に $Z / \nu^{7 / 2}$ そ 比例する. エネルギーの低い放射線の吸収はほとんどこの 現象によって起る. 電子が放出された後は $K$ 殼に空所が できるので $K_{\infty}$ の特性線を二次X線として放射する.

ii) Compton 効果 (Compton effect)

振動数 $\nu$ の放 射線がFig. 3 K 示すよう飞核外 電子または自由 電子と弾性徱突 して反跳電子 ( Recail electron ）を出し，放射

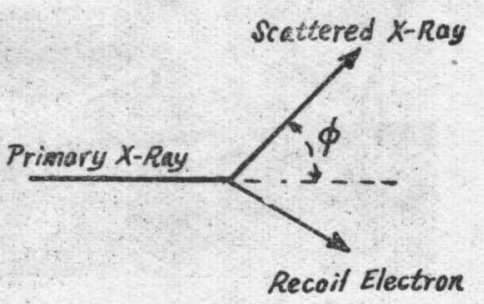

Fig. 3 Compton effect
線の波長が長くなって方向を変える現象である．との際一 次線の波長との差は散乱角 $\phi$ とすれば入射線の波長に関係 なく $0.242(1-\cos \phi) \AA$ である. 従って入射線の波長が短 いはど軟くなり方が大である. iii）陰陽電子生成（pair production）

エネルギーの高いX線， $\gamma$ 線が物質にあたった㭙電子核 の周りで光子が消滅し, 陰陽電子の刘が生成する. この対 の生成する最少のエネルギー㹥 2 つの電子のエネルギー $2 m c^{2}=1.2 \mathrm{MeV}$ で生成確率はエネルギーが高くなるとなも に著しく増加し，原子番号 Z の自乗に比例する．電子括よ び陽電子は入射光子とほよ゙同じ方向に放出される．しかし 陽電子の寿命が短く，直ちに陰電子と合して $0.5 \mathrm{MeV} の 2$ つの $\gamma$ 線の光子となり互に反対方向に放出する.

その他 Rayleigh 散乱等による減衰等もあるがこれは僅 かである.

以上の減衰様式による $I_{0}$ なる強さの人射線が吸収を受 け $I$ の強度の透過線となる. この $I_{0}$ と $I$ の関係は全吸収 係数を $u$ ，放射線の通過する長さを $t$ とすれば

$$
I=I_{0} e^{-u t \ldots . . .}
$$

の関係式が成立し, $u$ をさらに光電効果によるものCompton 効果によるるの，陰陽電子対生成によるものとに分けると

$$
u=u_{\text {photo }}+u_{\text {comp. }}+u_{\text {pair }}
$$

と書ける。

この $u$ を各種金属についてそのエネルギーの函数として 図示したすのが Fig. 42) である.

以上のような吸収がすこるため Fig. 2 と示すような散 乱線が現われ，透過像が不鮮明になる。，カセットの裹面に 鉛板を入れるのは散乱線を遮るためである．

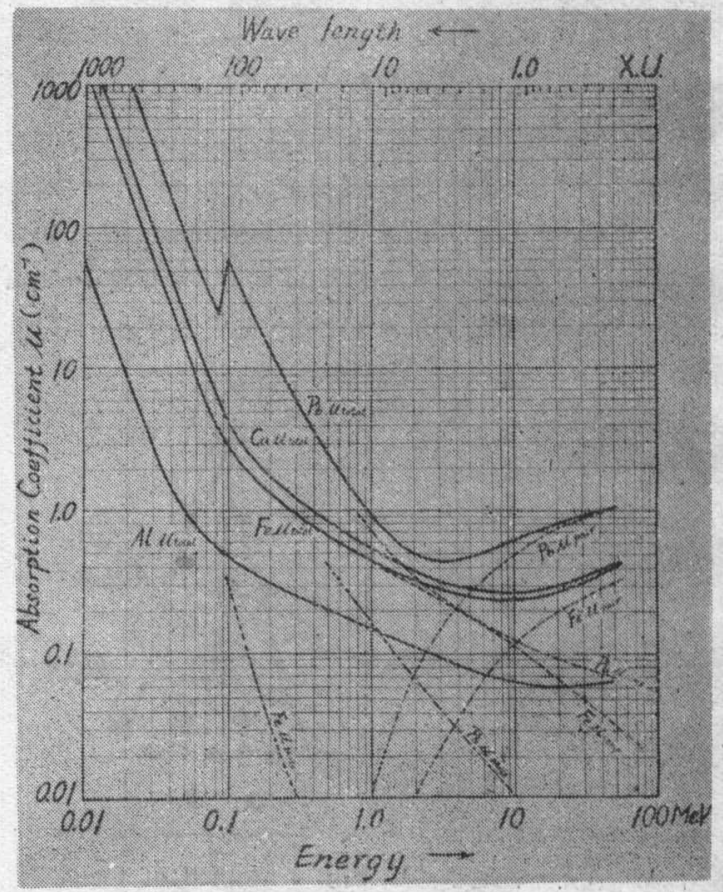

Fig. 4 Absorption coefficient

2) Handbook der physiks 括よびその他の Datum を 集めて表にしたものである. 


\section{$2 \mathrm{X}$ 線装瞋}

$\mathrm{X}$ 線装置は高速度の電子が物質に衝突した際そこから発 生するものであるから X線装置は電子を発生する部分括よ び電子が衝突する部分と，この電子を加速するため外部か らエネルギーを与竞る部分とからなる．すなわち前者の電 子発生部と衝突部は X 線管球であり, 後者は高王発生装置 または電梳加速装置からなる.

\section{X線管球}

X線管球はタングステンフィラメントを螺旋状または渦 巻状に巻いたものを陽極とし、タングステンの板を銅て鋳 込んだあのを対陰板としてガラスに封じ込み真空にしたも のである. フィラメントから放出され電子が収敛されて対 陰極に衝突するのであるが, その面積の大小が透過像の鮮 鋭度に影響する，従ってでき得るだけそのX線発生面積を 小さくした方がよい，しかしあまり小さい点て電子を集中 し過ぎると対陰極が熔解するから特殊なすのを除き現在工 業用 X線管の焦点は径 $3 \sim 5 \mathrm{~mm}$ が多い. 対陰極はフィラ メントに対し

Fig. 5 のよう そ傾いている ので撮影する 方向 $\mathrm{A}$ と B r 対して見掛上 の焦点の大き さが異なり， 像の鮮鋭度 (

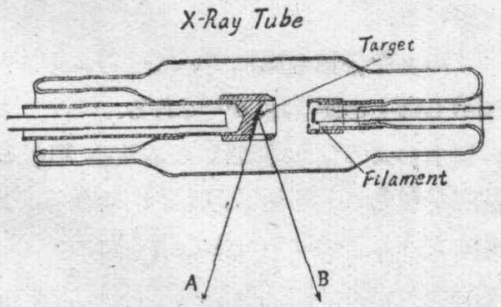

Fig. 5 X-Ray tube

解像力）に差を生ずる，従ってX線撮影漈しあらかじめ 焦点の大きさ，方向とよると見掛上の大きさを調べておく 必要がある. それには鉛板厚さ約 $0.5 \sim 1.0 \mathrm{~mm}$, 広さ $10 \times$ $10 \mathrm{~cm}^{2}$ 程度のむのと径 $0.2 \sim 0.3 \mathrm{~mm}$ の針穴を縦横 $1 \sim 2 \mathrm{~cm}$ 間隔にあけ，これを Fig. 6 のごとく焦点とフィルムの中 間飞把き，数十 $K V$ の 短時間露出によって撮 影すれば各方向から見 た見掛上の焦点が得ら れる. あし $A=2 a$ な らばフィルム上の影は 実物大の見猢の焦点を 示す. $A \neq 2 a$ のときる 幾何学的関係から大き さが計算される。この 像の異常から X線管球 の位置の異常も推定さ れる.

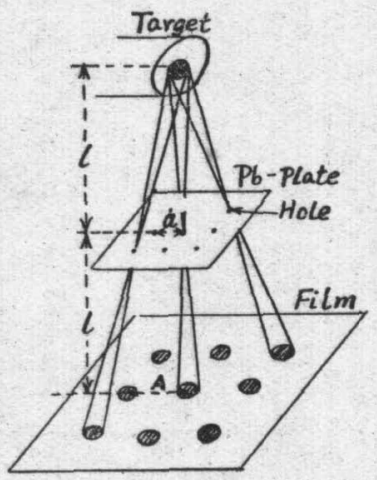

Fig. 6 Method of focus inspection
な打管球の名称は JISにより定められておりその名称 そより管球の性質を知ることができる. 例えば STO-200-6
とあれば SはX線遥蔽のないむの，Tは治潦用（工業用萧 用）…しかし工業用專用は T の代り I を用いるものああ 3. … 6 は最大使用管電流（平均 $\mathrm{mA}$ ) を示す，整流管て例えば KO-230 とあればKは熱陰極整流管 O は油浸式…Oの代 りにR とあれば空冷式…,230は最大尖䫓逆而電圧(KVP) を示す。

\section{2. 電子加速装置}

電子を加速するためフィラメントと対陰極間に高電圧を かけて加速する方法と磁場において加速する方法とが現在 用いられている.

i ）低周波高圧変圧器を用いる方法

50〜60サイクルの交流電圧を変圧器で高圧にする方法で この方式に次のようなるのがある。

a ) 自己整流方式

Fig. 7 のどとき結線 で小型のものに利用さ れることがあるが， $\mathrm{X}$ 線発生するのはフィ メント側が負になった 場合だけであり，その

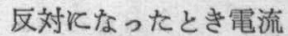
が零となるので逆電圧 が高くなる. そのため あまり用いられない。 故に逆電圧を括さえる ため 1 次側にケノトロ ンを入れた Fig. 8 の

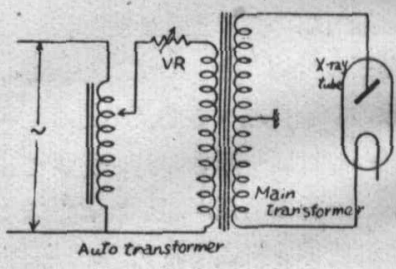

Fig. 7 Fundamental circuit diagram

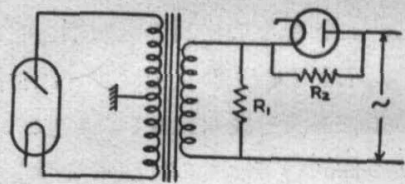

Fig. 8 Circuit diagram of back voltage reducer
ような結線方式が用いられる。 この方式では 2 次側にケノ トロンもコンデンサーもまたケーブルも必要なく，推带用 工業X線装置として用いられる. Photo 1 はその装置の 1 例を示す.

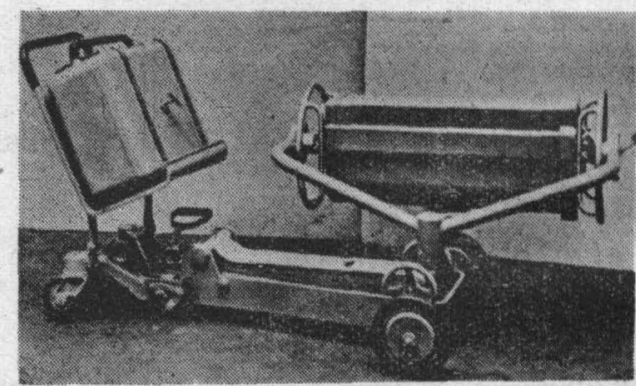

Photo. 1 175KVP. portable X-ray unit with back voltage reducer (R. Seifert \& Co.) b) 半波整流方式

自己整流方式の $\mathrm{X}$ 線管にか」る逆電生を軽隇するためケ ノトロンを挿入した方式で管電流を大きくとるときに有効 

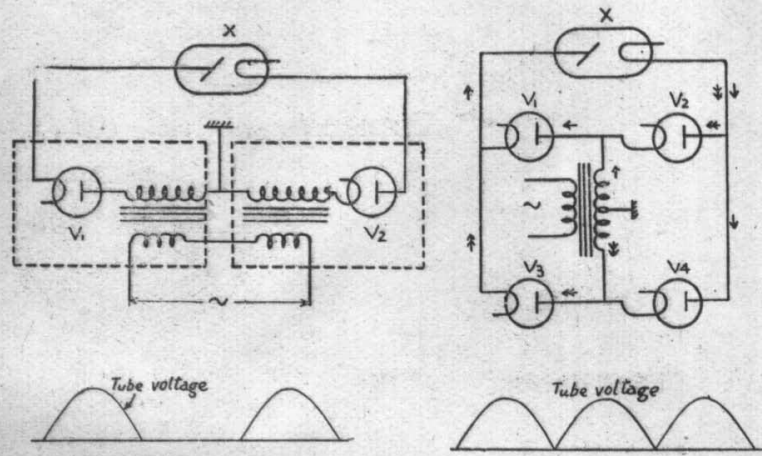

Fig. 9 Circuit diagram of half-wave connection

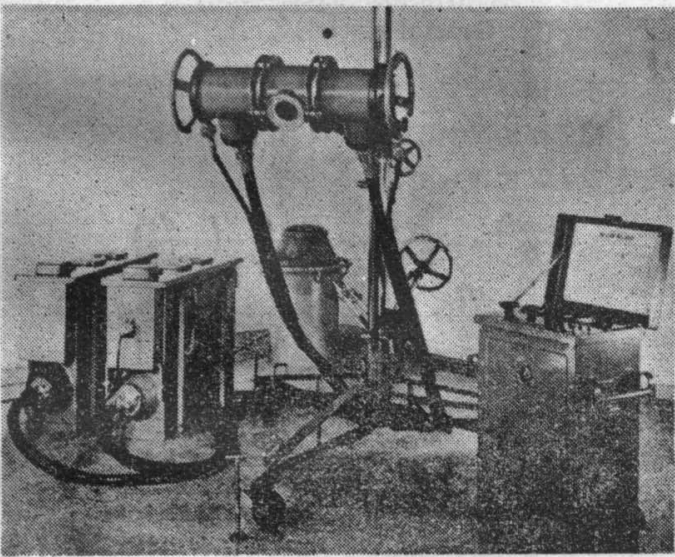

Photo. 2 300KVP X-ray unit with gveinacher connection (CHF. Müller)

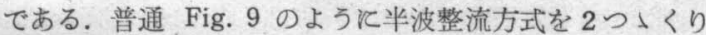
それぞれ分けて可搬型にしたものが多い，

c）両波整流方式

この方式には色々な回路があるがその代表的なものに Graetz, Villard, Greinacher, Zimmermaun-Witka 等の回 路がある. Graetz 回路 (Fig. 10) は一㭙に強いX線が欲 しい㭙に用いられ，Villord 回路はガレトンン回路ともい われ $200 \mathrm{KV}$ 以上のX線に用いられ管電圧は変圧器の電圧 の約 2 倍になる. Fig. 11 はそれを示す. Greinacher の回 路(Fig. 12)は電压の脉動が 非常に小さい回路で Photo 2 はその装置の1例を示す Zimmermann-Witka $の$ 回 路は 2 次電圧のほとんど 3 倍の電圧がX線にからる。 (Fig. 13)

以上の結線方式は 300 $400 \mathrm{KV}$ 程度までの装置に用 いられるが，それ以上にな

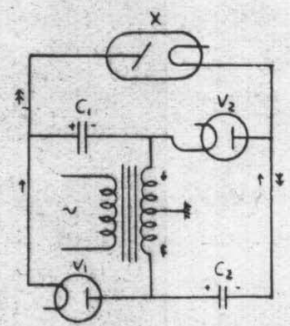

Fig. 13 Circuit diagram of zimmermann witka connection
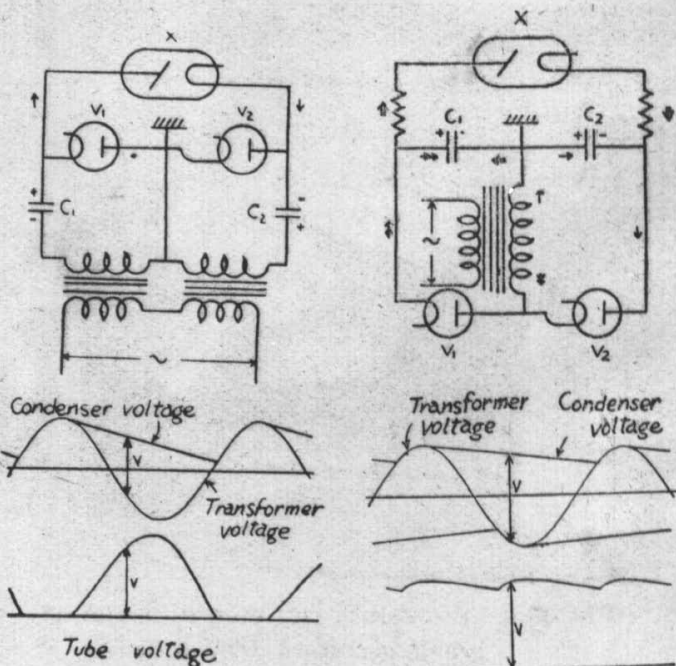

Fig. 11 Circuit diagram of villard connection

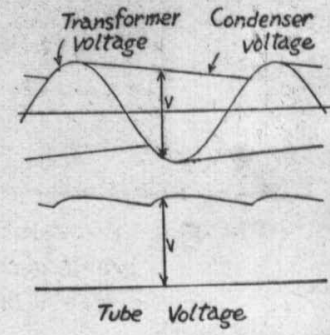

Fig. 12 Circuit diagram of greinacher connection

ると絶縁保持が困 難になるのて管球 と電源に新しい形 式が取入れなけれ ばならない、それ 飞は次のような方 式がある.

ii) Van de Graaff の装置

超高圧の X線源 として用いられる この方法は絹べ トのごときるのを 回転し, このべル トにコロナ放電で 带電させ, これを 收電子飞集めて高 压にする方法であ る. Fig. 14はその 原理を示 LPhoto. 3 は100万ボルト の装置である.

iii）共振変圧器 (Resonance Transformer)を用い る装置

電源飞高周波を 用い, その周波数

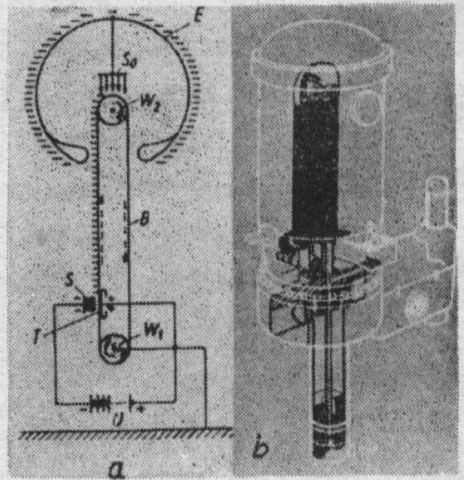

Fig. 14 Van de graaff generator (by O. Vaupel)

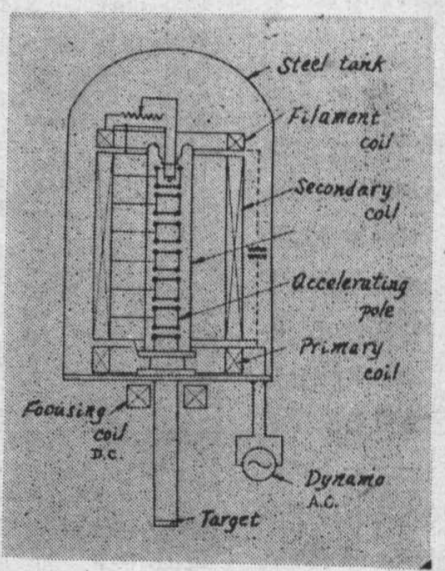

Fig. 15 Diagram of resonauce transformer 


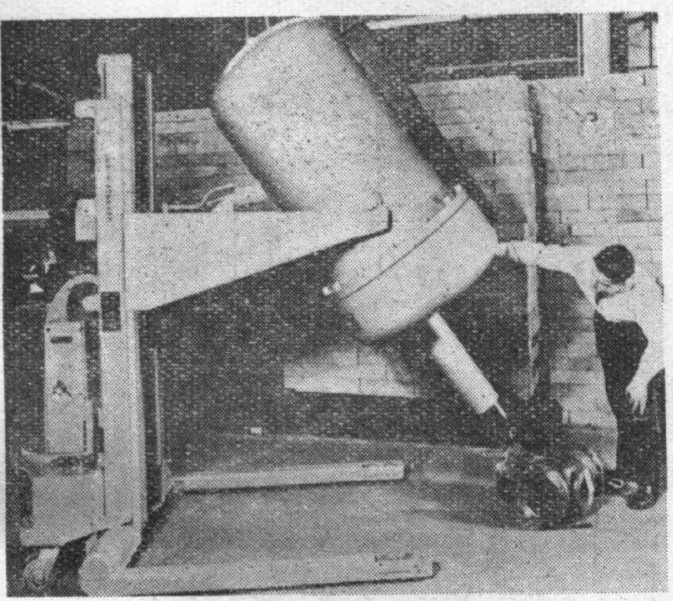

Photo. 3 Megavolt X-ray unit with van de graaff generator $1 \mathrm{MV} 0.25 \mathrm{~mA}$ (High volt. eng corp.)

回路のインダクタンス，キャパンチーならびそ抵抗の相互 作用によって回路中と共振現象を抢とさせて高電圧を発生 させる方法を用いたもので Fig. 15 はその原理図を示し， フレオンガス中にある空心 2 次コイルの共振によって生ず る高圧をとの軸上におかれた中間陽極を持つ X線管に与え るようにしたあので Photo. 4 はその装䆬で撮影中を示す。

iv) ベータートロン (Betatron)

電界強度が弱くともその電界中で電子の通過距離を長く すれば高速に加速できる．との原理を利用したもので磁束 を円内で变化すればその切線方向に電揚が生じ，その方向 に電子は加速される.すなわち Fig. 16 のような外鉄型変 圧器の鉄心の中央朋を切り，ドーナツ型加速管Dをはさん だあので, 中央 脚は切口が円形 で磁界が中心軸 飞対し完全な対 称となるようと し, 電子を数 $\mathrm{MeV}$ または数 $+\mathrm{MeV}$ のエ木 ルギーまで加速 してターダット 飞衝突させそ こからX線を発 生させる装置が ペータートロン である. 電子が 速度 $v$ で半径 $r_{s}$ の円運動する条 件は, $H_{s}$ を軌道

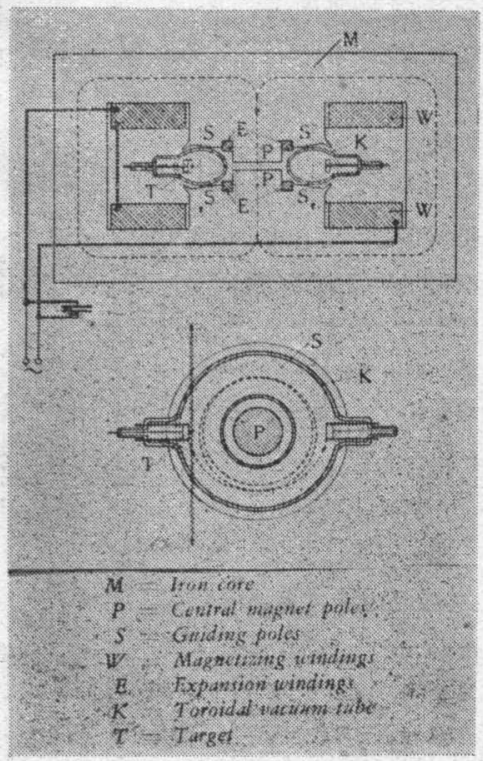

Fig. 16 Diagram of Betatron

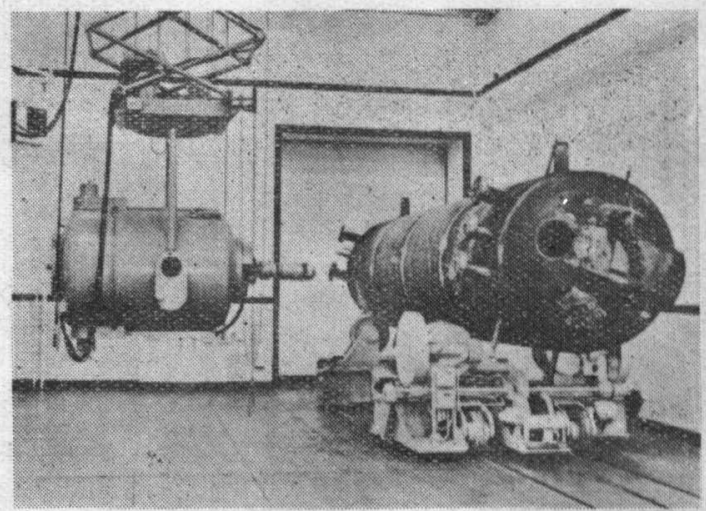

Photo. 4 Megavolt X-ray unit with resonance transformer $2 \mathrm{MV} 1.5 \mathrm{~mA}$ (General electric Co.)

面と垂直な磁界とすれば $e v H_{s}=m v^{2} / r_{s}$ が成立するととで ある. 電子が加速するのは円軌道内の磁束 $\phi$ の変化々よる 誘導起電力 $V$ とよってであるから

$$
\begin{gathered}
\quad \frac{d(m v)}{d t}=-\frac{e V}{2 \pi r_{s}}=-\frac{e}{2 \pi r_{s}}\left(-\frac{d \phi}{d t}\right) \\
\therefore \quad 2 \pi r_{s}{ }^{2} \frac{d H_{s}}{d t}=\frac{d \phi}{d t} \text { 積分すれぱ } 2 \pi r_{s}{ }^{2} H_{s}=\phi
\end{gathered}
$$

これは一様に $H_{s}$ の磁場が存在する場合の 2 倍の磁束を円 内に合むような条件である。この条件を満足すれに゙速度を 増しても $r_{s}$ なる円周上を運動することになる、電子が $r_{s}$ から少し位それても $r_{s}$ の軌道炕もどのよう磁界の $\gamma$ 方向 の変化をつけるため Fig. 16 のような極つ形につくる電子 は電子鏡から電流雾の状態より数 $\mu$ see ほど後に送り出し 中と $H$ が増加して安定軦道上に入り 1/4サイクルの終る少 乙前に中心部の磁束を飽和させるか，Fig. 16 そ示す $E$ の コイルで前の条件をくづせば電子が軌道からそれターグッ

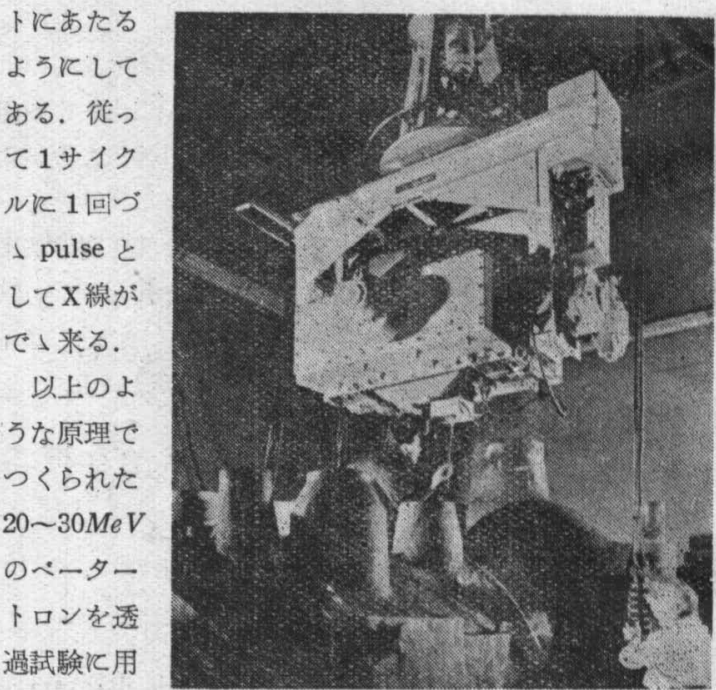
いられてい る.あまり

Photo. 5 22MeV Betatron (Allis-charmers MFG. Co.) 
エネルギーの大きい雨のは Fig. 4 より解るようと却って吸収が 大となり検查用に適しなくなる。 Photo. 5 はベータートロンの 1 例を示す. ベータートロンの焦 点は小さく径 $0.1 \mathrm{~mm}$ 以下にも できる：また X線の発生する角 度がエネルギーが大になると」

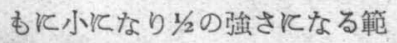

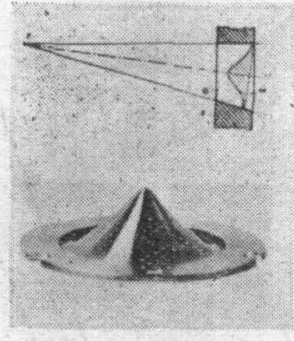

Photo. 6 Absorber
囲は $10 \mathrm{MeV}$ て $15^{\circ}, 30 \mathrm{MeV}$ て $5.7^{\circ}$ 程度である. 従って一 様な濃度の写真を撮影するためには適当な吸収物 (Photo、 6）を入れるかまたは焦点物体間の距離を大きくして物体 が焦点に張子角を小としなければならない。

\section{$3 \gamma$ 線源}

放射性同位元素が崩壊しまたは 子等を捕獲した励起状態にある原子核が $\gamma$ 線を放出して安 定になる. 従ってとれを利用すれば装置というるのを必要 とせず，強さが安定であり故障もおこらぬ．しかしX線装 置と異なり強さを変化できず強力な線源も得られない上に 単一波長からなるため同程度のX線に比しコントラストが 低くなる、また $\gamma$ 線は原子核内のエネルギー変化によって おこるため次第に放射能が弱くなる．とれは原子が変脱す る割合によりその割合はその㭙のその原子数に比例する ため結果として $e^{-\lambda t}$ ( $t$ はある時刻から測った時間, $\lambda$ は 元素に特有な常数）に比例して弱くなる. 强さが $1 / 2$ になる 時間を半減期 $(0.693 / \lambda)$ といらが Radiography 飞用らる 放射性同位元素はある程度以上の半減期を有するすのでな ければ実用にならぬ.しかし半減期が長いということは 1 定時間中に変脱する原子の数が变脱し得る能力のある原子 数比し少なくないととを意味するため，同じ強さの $\gamma$ 線 を得るためには半減期の短いものに比し多量を必要とす る. 従って焦点が大きくなる. 故に微焦点の強力な $\gamma$ 線を 得るためには半減期が短いものでなければならない，以上 の相反するた原因により実用上使用する放射性同位元素を 選択しなければならない，しかし同じ原素でも原子炀括よ びサイクロトロン内での当てる中性子, プロトンの密度, 照射時間等により $1 \mathrm{~g}$ あたりのキュリ一数, すなわち比放 射能 $\mathrm{c} / \mathrm{g}$ は異なる. 従って $\mathrm{c} / \mathrm{g}$ の最大なあのを使用する ことが望ましい.

$\gamma$ 線にも波長，すなわらエネルギーの異なるものがある ので検査する物体によって使用する元素を択ねばならぬ.

$\gamma$ 線は絶えず放射しているので使用しない時には放射線 を遥り，使用に際して人体を防護しながら操作できるよう な容器が色々と考案されている、 $\gamma$ 線源は普通アルミニウ ム製の Capsule そつめ, これを鉿, タングステン等によっ て作られた容器に入れておく， $\gamma$ 線のエネルギーが大であ
るほど,また強さ (Curie 数) が大で あるほど遮蔽用の 容器の壁を厚くし なければならない その厚され関して はSTAC の防護勧 告書に記してある Photo. 7 は容器の 1 例を示す. $\mathrm{Tm}^{170}$ (Thulium) の $\gamma$ 線のエネルギーは $84 \mathrm{KeV}$ で実効 100 $\mathrm{KVP}$ 程度の $\mathrm{X}$ 線

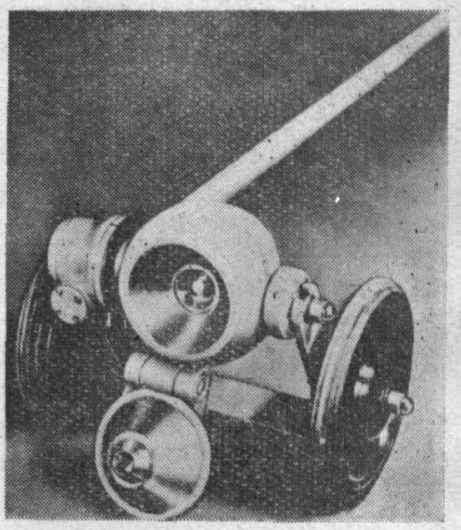

Photo. 7 Gamma source container
に相当するため容器も小さく Fig. 174) のどときものが使 用されている.

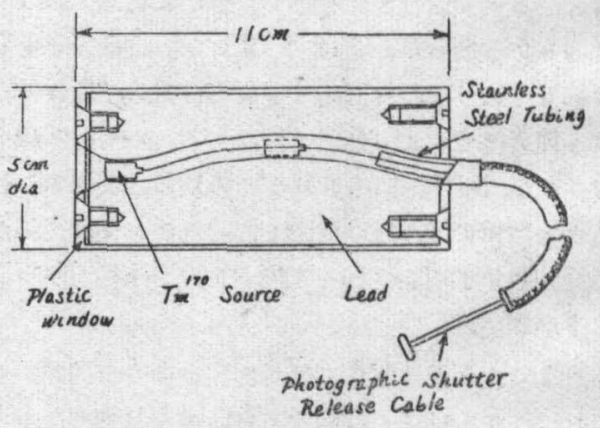

Fig. $17 \mathrm{Tm}^{170}$ source container

次に $\beta$ 線を利用した X 線装置 も考案されている.すなわち $\mathrm{Sr}^{90}$ (Strontium)を用いFig.184) のごとくこれを鉛て甘耳， $\mathrm{Sr}^{90}$ から出る $\beta$ 線によって鉛の特性 X線を出す方式である.これに よれば $74 \mathrm{KeV}$ にエネルギーの 極大を有する連続 X線が放出し $1 \mathrm{C}$ の $\mathrm{Sr}^{90}$ を用いればィ/2のアル ミニウムを1呎の距離でK type フィルムで4分間で撮影できる.

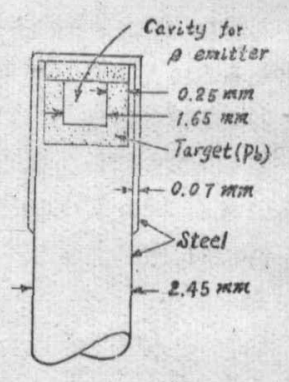

Fig. 18 Transmissiontarget source with $\mathrm{Sr}^{90}$

\section{X線装置ならびそ択射性同位原素の使用範囲}

以上のどとくエネルギーの異なる $\mathrm{X}$ 線括よび $\gamma$ 線を放射 する装置および元素をいかに使い分けるから問題となる。 (2)式によれぱいが厚いすのです露出㭙間を大にすれば 撮影できる筈である。しかしそこには経済的に成立つ㭙間 がある. X線は電源を要するので監視を要し長時間露出す
4) S. Untermyer ; Nueleonics 12 (1954) 5
5) L. Reiffel ; Nucleonics 3 (1955) 22 


\section{るととは不便であ} るが， $\gamma$ 線は設置 するだけであるか ら監視なしK，し かも夜間露出もで きるため多少の長 時間露出は不便を 来さない。

また久陌判別度 がらいえば撮影さ れたフィルムのコ ントラストが相当

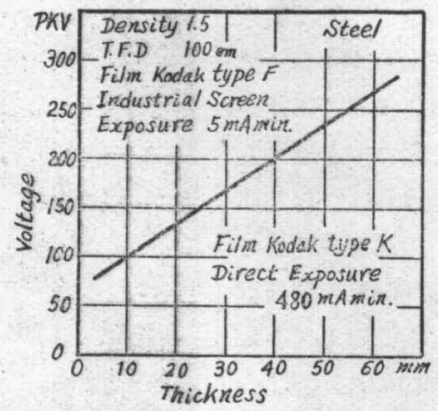

Fig. 19 Relation between thickness and voltage. (Exposure factor $=$ const $)$
問題になる. コントラストはフィルムともよるが透過し た物体の原さの差による透過エネルギーの差によるとと が多い，との差を適当につけるような放射線を択なけれ ばならない，軽合金には100KV以下の低電圧でしかあ長 波長をなるべく合むX線を用いた方がよい， $\gamma$ 線は一定 波長のみからなるため Fig. 1 のような波長分布を有す るX線（その KVP と対応する最短波長の強度な非常に 小さく極大はそれより低電圧側にある) に対し $\gamma$ 線のエ ネルギーの $\mathrm{KeV}$ (または $\mathrm{MeV}$ ) の数值は $\mathrm{X}$ 線のそれよ り大きな数值の KVP そ対応し，それより長波長部ない ため同じ数值で現わされるX線と $\gamma$ 線では後者がコント ラストが弱い。

あう 1 つの因子，解像力は焦面の大きさが問題になる がこれは線源の強さの問題であり, あまり強力なものは 焦点大きくなり解像力が落ちる。

Fig. 19 は撮影洔間を一定にしたときのX線管球に加 える電圧と鋼板の厚さの関係を示した. Fig. 20 は露出 表の 1 例であり，厚さによって使用し得る X線装置の容 量が見当つけられる。また $1 M V$ は $15 \mathrm{~cm}$ 程度, $10 \mathrm{MeV}$ 以上は $30 \mathrm{~cm}$ 程度の撮影飞用いられる。 $\gamma$ 線に刘しては Fig. 21 と示す露出表によりてその使範用が見当つけら る.

しかし以上の锶点もフィルム, 増感紙等によって左右 される性質のものであるが一般的にい亲ば許容される欠 陥の大きさは囪材の厚さに対する比で決められるので薄 物に対し高エネルギーのX線， $\gamma$ 線を使用することは好し くなく,なるへく与觉られた厚さと対し可能な限り低エホ

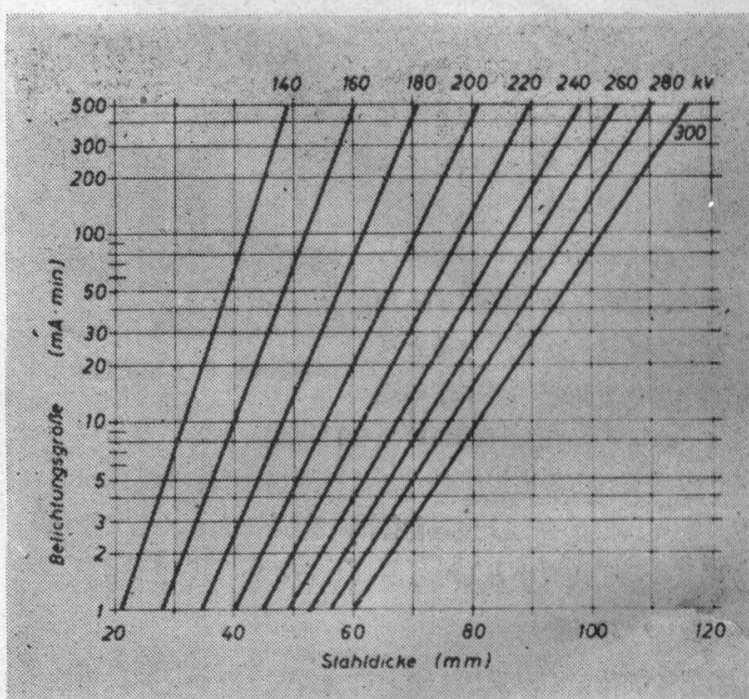

Density 1.0

Villard connection

H.S. Screen

Destauce $70 \mathrm{~cm}$

Fig. 20 Exposure chart for steel by $\mathrm{X}$-ray

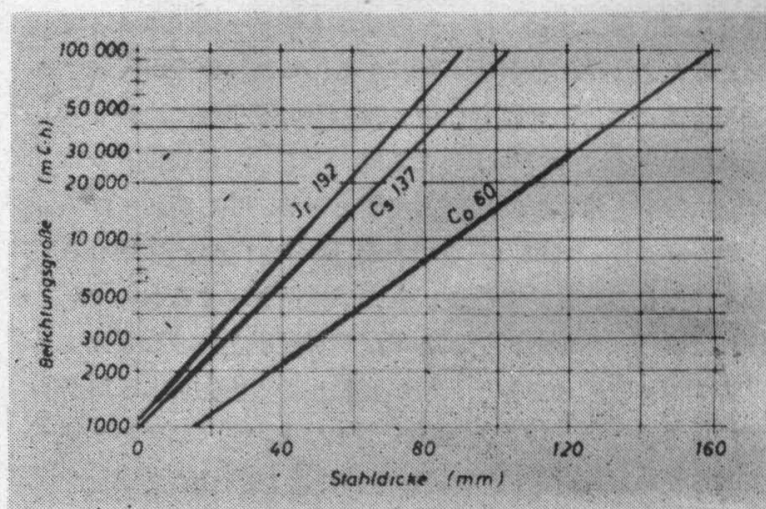

Density 1.5

$\mathrm{Pb}$ screen $0.01 / 0.15 \mathrm{~mm}$

Destance Co $70 \mathrm{~cm}$

Ir. Cs $50 \mathrm{~cm}$

Film inford $\mathrm{C}$

Fig. 21 Exposure chort for steel by $\gamma$-ray ルギーのX線，線を使用するととが望ましい。 